\title{
An Opinion Survey on FTP System among Branch Managers of Commercial Banks of Nepal
}

\author{
Chinta Mani Gautam'
}

\begin{abstract}
Funds Transfer Pricing (FTP) is a process that assigns funding costs to asset originators (loans) and funding credits to liability providers (deposits). It is one of the powerful and useful components of any profitability measurement system for financial institutions. This study aimed to survey the opinions of branch managers of Nepalese Commercial Banks in order to measure the awareness about FTP and to collect opinions regarding its practice in Nepal. A total of 140 branch managers were approached for the data collection. Out of them only 88 branch managers were found having awareness on FTP system. Therefore, detail analysis was made on the basis of responses of only 88 respondents. The survey revealed that Nepalese branch managers agree on the advantages of FTP system in bank branches, but they lacked enough skill of FTP system. The awareness of branch managers is depended more on there work experience than on job level of managers.
\end{abstract}

Key Words: Funds transfer pricing, Branch performance, Pooled approach, Pay on the net approach, Matched maturity pricing system

\section{INTRODUCTION}

In early days, bank branches were treated as a mini-bank to measure their performance. They used to be considered as standalone self-funding entities. For those branches which were heavy in loans and advances (assets), were allocated borrowings (deposit) in their balance sheet for 'force balance'. A short-term borrowing rate or average deposit costs were charged to those branches. Likewise, if branches were heavy in deposits (liability) side, investments (loans and advances) were allocated in their balance sheet for 'force balance' and respective return on investment rates were credited to them (Mioara \& Nicolae, 2009). This sort of simple measure of branch performance cannot give real picture of branch profitability.

1. Mr. Gautam is Teaching Assistant at Public Youth Campus, Tribhuvan University. Email : cmgakshay@gmail.com 
The major problem with this type of branch performance measurement was that there was no adjustment for mismatch risk. This is the risk introduced when a bank choose to fund long-term assets with short-term funds. Financial managers measure risk to earnings at the consolidated level rather than at the individual branch level (Kawano, 2005). This method also did nothing to measure the performance at the account level. Management needed a better method to measure performance. Financial managers began to look at branches in a different way. Rather than viewing branches as mini-banks, they began to look at them as retail stores, a summation of the products and services that they sold. And since mismatch risk doesn't exist in the products themselves but rather between products, this risk could be isolated and removed at the account level. From this approach funds transfer pricing entered into the banking system (Dimitriu \& Oaca, 2010).

Generally, commercial bank branches involve in accepting deposits and advancing loans, and they transfer/borrow the balance to/ from head office. Depending upon the type of the branch i.e. surplus or deficit, head office compensates the branches for transferring surplus funds or charges deficit branches at a notional price (Madurapperuma, 2009). This notional price is known as transfer price and the mechanism of fixing this price is known as transfer price mechanism (TPM).

From the practice of any branch banking system (ABBS), commercial banks frequently face asset liability (AL) mismatch (Burucs, 2008). Further, the AL mismatch is accelerated by the centralized decision of funds transfer among branches. For example, most of the Nepalese banks' corporate office takes decisions on the inter-branch fund transfer. The head office directs respective branches either they should transfer funds from their own another branch or should borrow from branches of other rival bank. In this situation, braches who are dependent to head office may not explore its efficiency on funds transferring decisions (Convery, 2003).

Over the period, banks are facing stiff competition to attain profit targets. Low interest rate spread has squeezed expected profit margins of the banks (Kocakulah \& Egler, 2006). Banks are forced to mobilize their resources to enhance their performance (Convery, 2003). Banks can earn profit only when they mobilize resources efficiently. Branch efficiency is measured through fund transfer pricing (FTP) system. This system improves profitability of branches through effective utilization of resources (Kimball, 1997). In this backdrop, this study aims to assess the level of awareness of branch managers about FTP system and to survey their opinions regarding its practice in Nepal.

\section{LITERATURE REVIEW}

Mainly three kinds of transfer pricing mechanism are used by banks to evaluate branch performance: Pooled Funds Transfer Pricing Approaches, Matched Maturity Pricing System, and Pay on the Net Method (Kugiel, 2009). 


\section{Pooled Funds Transfer Pricing Approaches}

Under pooled approach, head office or the funding department (treasury) assigns funds to one or more pools based upon pre-defined criteria and a specific set of dimensions. For example, criteria for pool classification may be based upon instrument type, term, repricing term, origination, or other fund attributes. This is an old method. The funding pool (treasury) supplies liquidity to branches (business units) at the pool rate. This rate is normally a market rate or market derived rate (Sharma, 2003). This approach too has some variants.

The single-pool rate approach: Assuming all funds have equal importance without consideration of their maturity single-pool approach uses one rate to both branches that provide funds or uses funds (Mioara \& Nicolae, 2009). The assigned transfer rate could be a weighted average cost of funds for the bank, the prime rate or some other capital market rate. It does not differentiate based upon the funds' attributes, provided or used, nor upon market conditions at the time of transaction origination. Though this approach is simple to use and understand, it is biased. Some branches will have an unfair advantage, while others will have an unfair disadvantage.

The dual-pool rate approach: Unlike single-pool rate approach, dual-pool rate approach uses two different rates - one for lending to head office and another for borrowing from head office. For example fund is lent to head office at $8 \%$ and borrowed at $9 \%$ (Sharma, 2003).

The multiple-pool rate approach: This is an extension of the single and dual pool rate approach. In this method, bank classifies assets and liabilities into pools based upon criteria such as maturity, embedded risk, seasoning, or credit. Each pool's assigned transfer rate is based upon the unique pool criteria. Pools from each side of the balance sheet are matched to pools on the opposite side to get to a related funds charge or credit. For example, long maturity pools receive a long-term rate while short-term pools receive a shorter term transfer rate. As compared to single and dual rate approaches, this approach is flexible and close to market reality; but it is complex to implement (Mioara \& Nicolae, 2009).

\section{Matched Maturity Pricing System}

Matched maturity pricing system is basically a gap approach. It is one of the effective but complex methods. It attempts to match the repricing period of assets (advance) with similar repricing for the liability (deposit) (Mioara \& Nicolae, 2009). Each individual customer account is matched to a market driven index such as the Treasury yield curve, the swap curve or LIBOR based curve. Transfer pricing rate represent the alternative opportunity rate for the banks sources or uses of funds and vary according to repricing term and other attributes (Burucs, 2008).

\section{Pay on the Net Method}

This approach uses the head office mirror account balance as the base for determining the amount of lending or borrowing done by the branches. If, in the books of head office, a particular branch balance is a debit balance reflecting an asset, then 
the branch borrows money from head office and head office charges interest on that borrowing. Similarly if, in the books of head office, there is a credit balance, meaning a liability, then the branch lends to head office and head office will pay interest to the branch (Madurapperuma, 2008). This approach ensures that all the funding by head office to a branch or by a branch to head office is captured.

However, effectively, this method is like running the excess or deficit of the branch through short-term savings accounts or overdrafts. A branch that has excess balances lends to the head office at the prevailing market rates. Similarly, a branch that has shortage of funds borrows from the head office at the predetermined rates. A few variants of this method can be identified depending on the method of determining the interest rate applicable.

Pay on the net method with single rate: In this case the interest rate applicable on borrowings by the branches and lending by the branches will be the same. There will be no differences on the rate for the sources and uses of funds.

Pay on the net method with dual rate: In this method, head office keeps a markup or spread between the borrowing rate and the lending rate. This mark up may be used to cover some other cost elements or to provide a disincentive on the borrowings by branches.

Pay on the net method with rates on slabs: In this approach, the interest rate applicable can vary depending on the amount of borrowing or lending. For example, the bank can decide that up to the level of funding as of the previous year or quarter end, the rate will be a certain percentage whereas beyond that it would be higher or lower. This, to an extent, can be used to control growth of advances or deposits as the case may be depending on the strategic objectives.

Many researchers and practicing managers have written about the FTP systems. Kocakulah (2004) and Burucs (2008) argue that transfer pricing helps bank mangers to measure and compare the branch profitability and efficiency. Branches of a bank are never the same in terms of deposits collection and advancing loans. Some branches are strong on the loan side, while others are good on the deposit side or are fairly balanced. Determining the profitability of individual branches in a traditional approach is improper; because a branch is heavy on the deposit side will look unprofitable, while a branch that is heavy on the loan side will look like it is highly profitable. Using the FTP system, cost of funds will be charged to all the loans that each branch has and will give a funding credit to all deposits that each branch has (Deventer, 2002).

Kugiel (2009) highlighted the significance of FTP system to manage liquidity and interest rate risk in a bank. Dimitriu \& Oaca (2010) introduced FTP as an analysis tool that can be used to measure its branch profitability in a variety of ways. Similar contribution was from Burucs (2008), Bowers (2006), Kocakulah (2004), etc. The FTP system help management to compare the profitability of different branches, and it can be drilled down even further to compare performance among individual employees. It is also very useful for comparison between branches (Shih, Crandon \& Wofford, 2004). 
Sharma (2003), Mudurapperuma (2008), Acharya and Merrouche (2008), have clearly argued that advance pooling with matched maturity method is the most appropriate method of FTP to neutralize interest rate and liquidity risk. Grant (2011) suggested the average cost rate for Liquidity Transfer Price (LTP). It is simple, but has two major defects. First, it neglects the varying maturity of assets and liabilities by applying a single charge for the use and benefit of funds and, second, it lags changes in banks actual market cost of funding. These defects essentially promote maturity transformation, which inherently exposes banks to more structural (mismatch/funding) liquidity risk (Bikker \& Bos, 2008). Overall, a matched-maturity marginal cost of funds approach promotes better LTP practice. It is more complex than the pooled average cost of funds approach, but it has some significant advantages. First, it recognizes that the costs and benefits of liquidity are related to the maturities of assets and liabilities, and therefore allows higher rates to be assigned to products that use or provide liquidity for longer periods of time. Second, it recognizes the importance of having changes in market conditions quickly and efficiently incorporated into the rate used to charge and credit users and providers of funds, and therefore relies on the actual market cost of funds (Dermine, 2012). Banks should be encouraged to move towards this approach, if they are not already doing so.

\section{RESEARCH METHODS}

This study was conducted using descriptive research design with opinion survey among 88 branch managers having enough knowledge on FTP system. As this study was the mailed opinion survey among bank branch managers, it takes all commercial bank's branch managers i.e. 1869 (NRB, July 2016) as a population of the study. Of the total bank branch managers, 335 branch managers were taken as a sample under convenient sampling techniques. Conveniently, those managers were selected, which were easily accessed, for examples, branch managers of Kathmandu valley; branch manager whose telephone number and email address was available, were included in the sample. First, email was send to 335 branch managers and tried to get their opinions; however, only 140 respondents' responses were obtained. Of the total 140 responses obtained, only 88 branch managers were found having enough knowledge on FTP system; therefore 88 are the final sample of the study. After reviewing returned questionnaires, a phone call was made to a few of branch managers for getting missing information.

\section{RESULTS AND DISCUSSIONS OF THE SURVEY}

\section{Respondents' Demographic Profile}

Table 1 shows the demographic profile of the 140 respondents on gender, age group, job level, and work experience. As seen in the table, an overwhelming majority $(92 \%)$ of the respondents are male. Most of the respondents are in the age group of 3140 years $(67 \%)$. Seventy percent of the respondents are either officer or senior officer and $91 \%$ have work experience of more than four years. 
Table 1: Demographic Profile of Respondents $(\mathrm{N}=140)$

\begin{tabular}{|c|c|c|c|c|c|}
\hline Demographics & Frequency & $\%$ & & Frequency & $\%$ \\
\hline \multicolumn{3}{|c|}{ Gender } & \multicolumn{3}{|c|}{ Level of Job } \\
\hline Male & 129 & 92 & Junior officer & 18 & 13 \\
\hline Female & 11 & 8 & Officer & 50 & 36 \\
\hline \multirow[t]{3}{*}{ Total } & 140 & 100 & Senior officer & 48 & 34 \\
\hline & & & $\begin{array}{l}\text { Assistant manager and } \\
\text { above }\end{array}$ & 24 & 17 \\
\hline & & & Total & 140 & 100 \\
\hline Age & & & \multicolumn{3}{|c|}{ Work Experience } \\
\hline Bellow 30 years & 7 & 5 & Bellow 4 years & 12 & 9 \\
\hline 31 to 35 years & 28 & 20 & 4 years to 8 years & 40 & 29 \\
\hline 36 to 40 years & 63 & 47 & 8 years to 12 years & 52 & 37 \\
\hline Above 41 years & 42 & 30 & 12 years and above & 36 & 26 \\
\hline Total & 140 & 100 & Total & 140 & 100 \\
\hline
\end{tabular}

\section{Opinion on the Criteria of Branch Efficiency Measurement}

Branches could be evaluated on the basis of various criteria. Six alternative criteria were provided in the questionnaire, and respondents were asked to rank them on the basis of their significance for measuring branch efficiency.

Table 2: Ranking the Criterion of Measuring Branch Efficiency

\begin{tabular}{lcc}
\hline \multicolumn{1}{c}{ Criterion of Measuring Branch Efficiency } & Mean Value & Rank \\
\hline Branch profitability & 1.05 & 1 \\
Non-performing assets & 3.18 & 3 \\
Target achievement & 1.85 & 2 \\
Lending ability & 4.17 & 4 \\
Deposit collection ability & 4.75 & 5 \\
Total & $\mathbf{1 4 0}$ & $\mathbf{1 0 0}$ \\
\hline
\end{tabular}

Almost all respondents considered the branch profitability as the major criterion for measuring branch performance with the mean value of 1.05 as shown in Table 2. The second and third ranked criteria were 'target achievement' and 'non-performing assets' with the mean value of 1.85 and 3.18 respectively. 'Lending ability' and 'deposit collection ability' were ranked as the fourth and fifth criterion. 
50 I PYC Nepal Journal of Management, August 2016, Vol. IX, No. 1

Awareness of the Branch Managers on FTP System

Out of the total 140 number of respondents surveyed only $63 \%$ (20\% having good knowledge and $43 \%$ having knowledge to some extent) branch managers were found aware with FTP system implemented on their bank. In other words, a significant proportion $(37 \%)$ of managers do not know about the FTP system (table 3 ),

Table 3: Level of Awareness of the Branch Managers on FTP System

\begin{tabular}{|c|c|c|}
\hline Alternatives & Frequencies & Percentage \\
\hline I have good knowledge on FTP & 28 & 20 \\
\hline I have knowledge on FTP to some extent & 60 & 43 \\
\hline I have no idea & 52 & 37 \\
\hline Total & 140 & 100 \\
\hline
\end{tabular}

Opinion on the Necessity of FTP System for Branch Performance Evaluation

FTP system provides a quantitative means to measure branch profitability and is used in the performance evaluations of branches and business units. When implemented and used effectively, FTP is expected to increase a bank's ability to monitor and improve its net interest margin (Tumasyan, 2000). With the purpose of finding how the branch managers do take the FTP system in branch performance evaluation, they were asked to give their opinion on the necessity of using internal funds transfer pricing system in commercial banks. Survey results have been presented in table 4:

Table 4: Opinion on the Necessity of FTP System for Branch Performance Evaluation

\begin{tabular}{lccc}
\hline & Alternatives & Frequencies & Percentage \\
\hline It is necessary & 85 & 97 \\
It is not necessary & 1 & 1 \\
I have no idea & Total & $\mathbf{8 8}$ & 2 \\
& & 2 & $\mathbf{1 0 0}$ \\
\hline
\end{tabular}

It was found in the survey that out of the 88 respondents who were aware with FTP system, 97\% considered FTP system necessary in the bank. In their opinion, fund transfer pricing system was necessary for the efficiency of financial institutions, and all commercial banks should implement one of FTP systems to improve branch performance. According to them, FTP was the best tool for allocating and analyzing net interest income, which is the largest component of bank's profits. Respondents further added that FTP system was fundamental for financial institutions and no bank could be well-managed without possessing some sort of transfer pricing system.

Further, to explore their opinion, another question - "Most branches are net funds generators or net funds users. Which should receive credit for the net interest margin earned on the asset or the liability overhang?" was asked to the respondents. 
Table 5: Opinion on the Net Interest Margin Earned on the Asset Liability Overhang

\begin{tabular}{lccc}
\hline & Alternatives & Frequencies & Percentage \\
\hline Net fund generator & 3 & 3 \\
Net funds users & 0 & 0 \\
Treasury department of the bank & 0 & 0 \\
Both net fund generator and users & 84 & 95 \\
If any, please specify... & Total & 1 & 1 \\
& $\quad \mathbf{8 8}$ & $\mathbf{1 0 0}$ \\
\hline
\end{tabular}

The response was consistent to the response given in Table 4. Out of the 88 respondents $95 \%$ respondents opinioned that the net interest income should be shared by both net fund generator and user. It shows the importance of FTP system in a commercial bank. Only $3.41 \%$ respondents opinioned that it should go to fund generator.

Opinion on the Benefits of FTP System for BFIs

Respondents were asked to give opinion on the benefits of funds transfer pricing system. They were asked to give weightage of 1 to 7 for highly significant to least significant level respectively.

Table 6: Opinion on the Benefits of FTP System for BFIs

\begin{tabular}{lcc}
\hline \multicolumn{1}{c}{ Benefits of FTP System for BFls } & Mean Value & Rank \\
\hline $\begin{array}{l}\text { Simplifies the net interest allocation to each branch } \\
\text { Allows calculating a cost of funds and applying them as a price to all internal } \\
\text { sources and uses of funds }\end{array}$ & 2.08 & 1 \\
$\begin{array}{l}\text { Allows planning, motivating and evaluating management performance based } \\
\text { on fair appraisal of results }\end{array}$ & 3.11 & 3 \\
$\begin{array}{l}\text { Permits removing interest rate risk from sales divisions by setting a fixed } \\
\text { margin on transactions, leaving only customer's credit risk }\end{array}$ & 6.02 & 6 \\
$\begin{array}{l}\text { Allows transferring interest rate and liquidity risk to a central unit responsible } \\
\text { for its management }\end{array}$ & 4.35 & 5 \\
Allows minimizing interest margin fluctuations due to market rate changes & 6.12 & 7 \\
Branches will be effective and efficient & 4.03 & 4 \\
\hline
\end{tabular}

Most of the respondents assigned more weight to "Simplifies the net interest allocation to each branch/business unit" with the lowest mean value of 2.08. Looking the mean values of ranks and their standard deviation $2 \mathrm{nd}$, 3rd, 4th, 5th ranked statements were (i) Allows calculating a cost of funds and applying them as a price to all internal sources and uses of funds, (ii) Allows planning, motivating and evaluating management performance based on fair appraisal of results, (iii) Branches will be effective and efficient, (iv) Allows transferring interest rate and liquidity risk to a central unit responsible for its management, respectively. The statements 'it prices marginal cost of funds in order to 
52 I PYC Nepal Journal of Management, August 2016, Vol. IX, No. 1

improve business decision making' and 'allows minimizing interest margin fluctuations due to market rate changes' were ranked 6th and 7th respectively.

Moreover, during telephone and face to face interviews, some of respondents added that fund transfer pricing provides the following additional benefits other than those listed in the questionnaire. They are:

- Facilitates management of market risk through assets and liabilities management

- Facilitates detailed analysis of interest income, by product, branch, business line, transaction, etc.

- Interest income decomposition improves product pricing and tailoring the product offer to various needs

- Permits removing interest rate risk from sales divisions by setting a fixed margin on transactions, leaving only customer's credit risk

- Allows minimizing interest margin fluctuations due to market rate changes

Opinion on the Authority / Responsibility of Setting FTP Rate

Respondents were asked to give their opinion on the authority / responsibility of setting FTP rate. Most of the respondents i.e. $81 \%$ gave opinion that asset-liability management committee (ALCO) should determine the FTP rate.

Table 7: Opinion on the authority / responsibility of setting FTP rate

\begin{tabular}{|c|c|c|}
\hline Alternatives & Frequencies & Percentage \\
\hline Fund provider branch & 4 & 5 \\
\hline Fund receiver branch & 0 & 0 \\
\hline Treasury department & 3 & 3 \\
\hline Assets liability management committee (ALCO) & 71 & 81 \\
\hline Through the bargain between fund provider and fund receiver branch & 10 & 11 \\
\hline Total & 88 & 100 \\
\hline
\end{tabular}

About $11 \%$ respondents gave opinion on the setting FTP rate through the bargaining between fund provider and receiver branch. Less than $5 \%$ respondents opinioned that the rate should be determined by fund receiving branch and treasury department.

\section{FTP Method Used by Nepalese BFIs}

Survey among 88 bank managers who have knowledge on FTP system responded on the methods that their banks have been using to price the fund transferred from one branch to other. The result has been presented in Table 8. 
Table 8: Methods of FTP System Practiced by Banks

\begin{tabular}{|c|c|c|}
\hline Methods & Frequencies & Percentage \\
\hline The single-pool rate approach & 4 & 5 \\
\hline The dual-pool rate approach & 30 & 34 \\
\hline The multiple-pool rate approach & 12 & 14 \\
\hline Matched maturity pricing system & 8 & 9 \\
\hline Pay on the net method with single rate & 28 & 32 \\
\hline Pay on the net method with dual rate & 6 & 7 \\
\hline Pay on the net method with rates on slabs & 0 & 0.00 \\
\hline Total & 88 & 100 \\
\hline
\end{tabular}

Survey result that $34 \%$ of the respondents respond their bank uses 'dual-pool rate approach' and $32 \%$ respond 'pay on the net method with single rate'. Another $14 \%$ responded to 'multiple-pool rate approach'. 'Pay on the net method with rates on slabs' has not been used by the sample banks and the remaining $10 \%$ of respondents answered for other methods.

\section{Opinion on the Appropriate Method of FTP System}

As discussed in the introduction section, it may be wise to credit the funding center for the assets provided. Thus interest income should be shared to both fund generator and fund users. This sharing depends upon the mix of assets and liabilities. Only appropriate FTP method will give credit of the net interest income to right branches.

There are various methods developed for funds transfer pricing. The pros and cons of each method were assessed in the literature review section. An opinion survey was made on the selection of appropriate method of funds transfer pricing on their banks. The result has been summarized in Table 9 .

Table 9: Appropriate Method of FTP System

\begin{tabular}{|c|c|c|}
\hline Methods & Frequencies & Percentage \\
\hline The single-pool rate approach & 0 & 0 \\
\hline The dual-pool rate approach & 1 & 1 \\
\hline The multiple-pool rate approach & 28 & 32 \\
\hline Matched maturity pricing system & 24 & 27 \\
\hline Pay on the net method with single rate & 0 & 0 \\
\hline Pay on the net method with dual rate & 35 & 40 \\
\hline Pay on the net method with rates on slabs & 0 & 0 \\
\hline Total & 88 & 100 \\
\hline
\end{tabular}

Out of the 88 respondents $40 \%$ selected 'pay on the net method with dual rate' as an appropriate method to be implemented. The second most popular approach was found 'multiple-pool rate approach' with the vote of $32 \%$ respondents. Similarly, $27 \%$ of 
respondents selected 'advance pooling with matched maturity pricing system'. Only 1\% respondents selected 'pooling funds with a dual rate'.

It is to be noted that in the literature survey, it is found that 'the matched-maturity transfer prices' and then adjusting for standby liquidity and collateral costs for secured transactions was one of the preferred choices. However, he branch managers did not find this method as a popular method. It clearly depicts that there is not depth awareness of FTP system among branch managers whom this study has listed as aware branch managers.

\section{Association between Job Level of Branch Managers and Awareness on FTP System}

The level of job held by the respondent is considered a possible factor influencing awareness of branch mangers on FTP system. Thus its effect is evaluated using Chisquare tests. Table 10 presents the Pearson's Chi-squire with its P-value. This P-value indicates that there is not significant different between level of branch managers and their awareness on FTP system.

Table 10: Chi-Square Tests Statistic (Job Level and Awareness)

\begin{tabular}{cccc}
\hline & Value & df & Asymp. Sig. (2-sided) \\
\hline Pearson Chi-Square & 2.334 & 139 & .2351 \\
\hline
\end{tabular}

Association between Work Experience of Branch Managers and Awareness on FTP System

The variable work experience of branch managers is taken to test their awareness on FTP system. The result of Chi-square test with its $P$ value has been shown in Table 11. The P-value indicates that there is not significant different between work experience of branch managers and their awareness on FTP system.

Table 11: Chi-Square Tests Statistic (Work Experience and Awareness)

\begin{tabular}{cccc}
\hline & Value & df & Asymp. Sig. (2-sided) \\
\hline Pearson Chi-Square & 102.031 & 139 & .000 \\
\hline
\end{tabular}

Further the Table 12 shows that about $82 \%[=(19+13) / 39]$ branch managers who have work experience above 12 years responded that they are aware with FTP system. Similarly, $69 \%[=(13+7) / 29]$ branch managers who have work experience between 8 to 12 years also have knowledge on FTP system. However, 51\% = [21/41] branch managers who have work experience of 4 to 8 years and $52 \%$ [=21/31] branch managers who have work experience of bellow 4 years have no idea about FTP system. 
Table 12: Cross Tabulation of Work Experience and Awareness on FTP System

\begin{tabular}{ccccc}
\hline \multirow{2}{*}{$\begin{array}{c}\text { Work Experience } \\
\text { (in years) }\end{array}$} & \multicolumn{3}{c}{ Awareness on FTP System } & Total \\
\cline { 2 - 4 } & Good Knowledge & To Some Extent & No Idea & \\
\hline Bellow 4 years & 8 & 8 & 15 & 31 \\
4 to 8 years & 14 & 6 & 21 & 41 \\
8 to 12 years & 13 & 7 & 9 & 29 \\
12 years and above & 19 & 13 & 5 & 39 \\
Total & $\mathbf{5 4}$ & $\mathbf{3 4}$ & $\mathbf{5 2}$ & $\mathbf{1 4 0}$ \\
\hline
\end{tabular}

\section{CONCLUSION}

Overall, banks need to employ one of FTP methods in order to be able to analyze contributions to overall interest profit, to control and evaluate business results. Lack of a proper FTP system negatively influences bank's overall profits and deteriorates the ability of risk control as stated by Convery (2003); Burucs (2008); Kimball (1993); Madurapperuma (2008). But, practice of FTP system will be more effective if it is known by head of business units.

With the knowledge of FTP system, a branch manager understands how its branch profitability is measured, what factor contributes their profitability. However, this survey found that a significant share of branch managers still lacked proper knowledge of FTP system. Only 88 of 140 did respond the survey. Further, the branch managers do not have significant role on decision making of FTP rate and methods. Most of them are not responsive to FTP system implemented over them. It is also found that awareness of branch managers is dependent more on their work experience than on job level of managers.

Survey result showed that majority of the banks use 'dual pool rate approach' of FTP, however the majority chose 'multiple pool rate approach'. It indicates that majority of Nepalese commercial banks still lack adequate knowledge to implement proper FTP system.

\section{REFERENCES}

Acharya, V. V., \& Merrouche, O. (2008). Precautionary hoarding of liquidity and inter-bank markets: Evidence from the sub-prime crisis. Retrieved from http://pages.stern.nyu.edu/ sternfin/vacharya/ public_html/acharya_merrouche.pdf.

Bikker, J. A., \& Bos, J. W. (2008). Bank performance: a theoretical and empirical frame work for the analysis of profitability, competition and efficiency. New York: Routledge International Studies in Money and Banking.

Bowers, T. (2006). Transfer pricing indeterminate-maturity deposits. Journal of Performance Management. Retrieved from: HighBeam Research:https://www.highbeam.com/doc/1P3-1043553521.html

Buruc, J. (2008) Thoughts about employing funds transfer pricing. International Finance Corporation. Business Week. Retrieved from: http://www.businessweek.com/ magazine/content/09_34/ b4144048821798.htm 
56 I PYC Nepal Journal of Management, August 2016, Vol. IX, No. 1

Chittenden, J. (2000), A bank's focal point for market risk: The transfer pricing mismatch unit. Journal of Bank Cost and Management Accounting, 13(1), 3-23.

Coffey, J. (2001). What is fund transfer pricing. ABA Bank Marketing, 33 (9).

Convery, S. (2003). Keeping banks competitive: a foundation for robust performance management. Balance Sheet, 11(3).

Dermine, J. (2012). Fund transfer pricing for deposits and loans, foundation and advance. Retrieved from: http://www.insead.edu/facultyresearch/research/search_papers.cfm

Deventer, D. (2002). Transfer pricing systems design: building clarity in the responsibility for and measurement of risk. US: Kamakura Corporation. Retrieved from: http://www.kamakuraco.com/ Portals/0/doclibrary/WP5.pdf

Dimitriu, M. C., \& Oaca, S. C. (2010). Funds transfer pricing in banking. Economia: Seria Management, 13(1), 119-127.

Edlin, A., \& Reichelstein, S. (1995). Negotiated transfer pricing: An efficiency result. The Accounitng Review, 70(2), 479-494.

Ernst \& Young (2003). Global transfer pricing survey. Retrieved from: www.ey.com

Gautam, C. M. (2012). Funds transfer pricing system in Nepalese commercial banks. (An unpublished M. Phil thesis, Tribhuvan University).

Grant, J. (2011). Liquidity transfer pricing: A guide to better practice. Australia: Australian prudential regulation authority.

Kawano, R. T. (2005). Funds transfer pricing. Journal of Performance Measurement, 35-43

Ken, L. (2008). Beyond funds transfer pricing to actionable decesion-making . Journal of Performance Management, 21(1).

Kimball, R. C. (1993). Calculating and using risk-adjusted ROE for lines of business. Bank Accounting and Finance, 17-27.

Kimball, R. C. (1997). Innovations in performance measurement in banking. New England Economic Review, 23-38.

Kocakulah, M. (2004). Funds transfer pricing: A management accounting approach within the banking industry. Journal of Performance Management, 17 (2).

Kocakulah, M., \& Egler, M. (2006). Funds transfer pricing: How to measure branch profitability. Journal of Perfomance Measurement . Retrieved from: http://findarticles.com/p/articles/mi_qa4148/ is_200601/ai_n16431094/

Kugiel, L. (2009). Fund transfer pricing in a commercial bank. (An unpublished MSC thesis, Aarhus School of Business).

Liewellyn, D. T. (2005). Competition and profitability in European banking: Why are British banks so profitable? Retrieved from: Blackwell-Synergy.com.

Madurapperuma, A. (2008). Internal transfer pricing: A means of rational resource allocation in banks. 20th Anniversary Convention. Columbo: Seylan Bank .

Mioara, M., \& Nicolae, C. (2009). Performance measurement in banking: Funds transfer pricing (FTP). Review of International Comparative Managment. Retrived from www.google.com

Payant, R. W. (2000). Funds transfer pricing and A/L modeling. Journal of Bank Cost \& Management Accounting . 13(1), 12-16

Payant, R. W. (2004). To FTP or not to FTP - that is the question!. Journal of Performance Management . $17(2), 27-32$

Rice, J., \& Kocakulah, M. (2004). Funds transfer pricing: A management accounting approach within the banking industry. Journal of Performance Management, 17(2), 3-13.

Sharma, S. N. (2003). Transfer price mechanism for branch evaluation - a dynamic approach. Management 
Accountant, 38(4), 245-250

Shih, A., Crandon, D., \& Wofford, S. (2000). Transfer pricing: Pitfalls in using multiple benchmark yields curves. Journal of Bank Cost \& Management, 17, 33-46.

Shih, A., Crandon, D., \& Wofford, S. (2004). Transfer pricing: Pitfalls in using multiple benchmark yield curves. Journal of Performance Management, 17, 2 .

Tumasyan, H. (2000). RAPM, Funds transfer pricing and risk capital. Journal Services. Retrieved from: http://ssrn.com/abstract=2257081 or http://dx.doi.org/10.2139/ssrn.2257081

Turner, S. (2008). Funds transfer pricing: Cracking the code on deposit valuation. Novantas Strategy and Managment. White Paper Series

Wei-Shong, L. P., \& Kuo-Chung, M. A. (2006). The internal performance measures of bank lending: a valueadded approach. Benchmarking: An Internaitonal Journal , 13(3), 272-289.

Wyle, R. J., \& Tsaig, Y. (2011). Implementing high value funds transfer pricing system. Moody's Analytic. 


\section{"An Opinion Survey on FTP System among Commercial Bank Branch Managers"}

Dear Respondents,

This is Chinta Mani Gautam, an academician involving in teaching graduate level accounting courses in Public Youth Campus, doing a research on "An Opinion Survey on FTP System among Commercial Bank Branch Managers ". My purpose of the research is to contribute knowledge in funds transfer pricing. It is not intended to serve to any institution. It is independent academic study. I am seeking your assistance as I have selected you randomly for survey purpose. You will represent to whole branch managers of banking industry without mentioning your name.

I, therefore, cordially request you to spare a few minutes of valuable time to fill this questionnaire. I require your personal opinion on the subject. The information furnished by you shall be kept confidential and used only for academic purpose. The data shall not be compared with individual respondents. If you have any queries regarding the questionnaires, please do not hesitate to contact at cmgakshay@gmail.com. Thank you for your precious time and participation.

Please provide the following information:-
Q.1 Gender:
(1) Male [ ]
(2) Female [ ]
Q.2 Age (years):
(1) Bellow 30 [ ]
(2) 31 to 35 [ ]
(3) 36 to 40 [ ]
(4) 41 and above [ ]
Q.3 Level of job:
(1) Junior officer [ ]
(2) Officer level [ ]
(3) Senior officer [ ]
(4) Assistant manager and above [ ]

Q.4 Working experience in the BFIs:
(1) Below 4 years [ ]
(2) 4 years to 8 years [ ]
(3) 8 years to 12 years [ ]
(4) 12 years and above [ ]

Q.5 In your opinion, what criteria should be used to measure the branch efficiency in Nepalese Commercial bank? Rank 1 to 5 from highest to lowest level.

1. Branch profitability [ ]

2. Non Performing Assets of branch [ ]

3. Target achievements [ ]

4. Lending ability of branch [ ]

5. Deposit collection ability of branch [ ]

Q.6 How do you rate your awareness with Fund Transfer Pricing (FTP) System?

1. I have good knowledge on FTP [ ]

2. I have knowledge on FTP to some extent [ ]

3. I have no idea [ ]

Q.7 (Answer this question if you select option 1 or 2 of Q. 6.) In your opinion, is it necessary to use funds transfer pricing system?
1. Yes [ ]
2. No [ ]
3. No idea [ ] 
Q.8 If yes, what are its benefits for a financial institution? Rank 1 to 7 from highest to lowest level.

1. Simplifies the net interest allocation to each branch [ ]

2. Allows calculating a cost of funds and applying them as a price to all internal sources and uses of funds [ ]

3. Allows planning, motivating and evaluating management performance based on fair appraisal of results [ ]

4. Permits removing interest rate risk from sales divisions by setting a fixed margin on transactions, leaving only customer's credit risk [ ]

5. Allows transferring interest rate and liquidity risk to a central unit responsible for its management [ ]

6. Allows minimizing interest margin fluctuations due to market rate changes [ ]

7. Branches will be effective and efficient [ ]

Q.9 Most branches are net funds generators or net funds users. Which should receive credit for the net interest margin earned on the asset or the liability overhang? [ ]

1. Net fund generator [ ]

2. Net funds users [ ]

3. Treasury department of the bank [ ]

4. Both net fund generator and users [ ]

5. If any, please specify.........

Q.10 In your opinion, who should set FTP rate?

1. Fund provider branch [ ]

2. Fund receiver branch [ ]

3. Treasury department [ ]

4. Assets liability management committee [ ]

5. Through the bargain between fund provider and fund receiver branch

Q.11 What method of transfer price has been used in your bank to price the fund transferred from surplus branch to deficit branch?

1 The single-pool rate approach [ ]

2 The dual-pool rate approach [ ]

3 The multiple-pool rate approach [ ]

4 Matched Maturity Pricing System [ ]

5 Pay on the Net Method with single rate [ ]

6 Pay on the net method with dual rate [ ]

7 Pay on the net method with rates on slabs [ ]

Q.12 In your opinion, what system of funds transfer pricing is appropriate in Nepalese Banking Sector?

1 Single-pool rate approach [ ]

2 Dual-pool rate approach [ ]

3 Multiple-pool approach [ ]

4 Matched maturity pricing system [ ]

5 Pay on the net method with single rate [ ]

6 Pay on the net method with dual rate [ ]

7 Pay on the net method with rates on slabs [ ] 